\title{
Identification of a New Powdery Mildew Resistance Gene pmDHT at or Closely Linked to the Pm5 Locus in the Chinese Wheat Landrace Dahongtou
}

\author{
Yanmin Qie, ${ }^{1}$ Yuan Sheng, ${ }^{1,4}$ Hongxing Xu, ${ }^{1}$ Yuli Jin,,${ }^{1,4}$ Feifei Ma, ${ }^{1}$ Lihui Li, ${ }^{3}$ Xiuquan Li, ${ }^{3}$ and Diaoguo An ${ }^{1,2, \dagger}$ \\ ${ }^{1}$ Center for Agricultural Resources Research, Institute of Genetics and Developmental Biology, Chinese Academy of Sciences, \\ Shijiazhuang, Hebei 050021, China \\ 2 The Innovative Academy of Seed Design, Chinese Academy of Sciences, Beijing, China \\ ${ }^{3}$ National Key Facility for Crop Gene Resources and Genetic Improvement, Institute of Crop Science, Chinese Academy of \\ Agricultural Sciences, Beijing 100081, China \\ ${ }^{4}$ University of Chinese Academy of Sciences, Beijing 100049, China
}

\begin{abstract}
Chinese wheat landrace Dahongtou was resistant to 35 of 38 tested Chinese isolates of Blumeria graminis f. sp. tritici at the seedling stage. Genetic analysis of the $\mathrm{F}_{2}$ populations and their derived $\mathrm{F}_{2: 3}$ families of crosses of Dahongtou with the susceptible varieties Mingxian 169 and Huixianhong indicated that the resistance of Dahongtou to B. graminis f. sp. tritici isolate $\mathrm{E} 09$ was conferred by a single recessive gene, tentatively designated as $p m D H T$. The gene was mapped to chromosome arm 7BL and flanked by markers Xwmc526/XBE443877 and Xgwm611/Xwmc511 at genetic dis-

$(m l x b d)$ indicated that $p m D H T$ was allelic to both Pm5e and $m l x b d$. However, $p m D H T$ showed a different pattern of resistance to the $38 \mathrm{~B}$. graminis f. sp. tritici isolates compared with wheat lines with Pm5a, Pm5b, Pm5e, $m l x b d$, and PmHYM and also differed from PmSGA. Thus, pmDHT was identified most likely as a new allele or at least a closely linked gene of the Pm5 locus. This gene can be transferred into susceptible wheat cultivars/lines and pyramided with other resistance genes through marker-assisted selection to improve powdery mildew resistance.
\end{abstract} tances of 0.8 and $0.3 \mathrm{cM}$, respectively. The chromosomal position of pmDHT was similar to the multi-allelic Pm5 locus on 7BL. Allelism tests with crosses of Dahongtou with Fuzhuang 30 (Pm5e) and Xiaobaidong
Keywords: powdery mildew, pmDHT, mapping, Chinese wheat landrace, Pm5 locus
Powdery mildew, caused by the Blumeria graminis (DC) Speer $\mathrm{f}$. sp. tritici emend É J Marchal, is an important foliar disease, and it can cause significant grain yield reductions in many wheat-growing regions of the world (Bennett 1984; Johnson et al. 1979; Morgounov et al. 2012). So far, applying fungicides and growing resistant cultivars are most effective methods for managing powdery mildew (Deising et al. 2002). Although fungicides are effective for reducing yield losses, use of fungicides adds significant costs for wheat production and may have adverse effects on the environment (Bennett 1984; Bliffeld et al. 1999). Developing and growing resistant wheat cultivars are considered to be the most effective, economical, easy to use, and environmentally friendly approaches for controlling wheat powdery mildew. The most widely used and researched resistance sources are the major resistance genes conferring race-specific resistance (Xing et al. 2018; Zou et al. 2018). However, such resistance genes can be defeated by new virulent races or races that have been present at very low frequencies in the pathogen population but can become widespread under new selection pressure (McDonald and Linde 2002). Therefore, it is essential to explore, identify, and utilize

${ }^{\dagger}$ Corresponding author: D. An; dgan@sjziam.ac.cn

Y. Qie, H. Xu, and Y. Sheng contributed equally to this work.

Funding: This research was financially supported by National Key Research and Development Program of China grant 2016YFD0102002, National Natural Science Foundation of China grants 31771793 and 31671771, and STS Project of Chinese Academy of Sciences grant KFJ-STS-ZDTP-024.

*The $\boldsymbol{e}$-Xtra logo stands for "electronic extra" and indicates that one supplementary table is published online.

The author(s) declare no conflict of interest.

Accepted for publication 19 April 2019.

C 2019 The American Phytopathological Society new sources of broad-spectrum resistance on a continuing basis to obtain more durable resistance to powdery mildew (He et al. 2018).

More than 70 formally designated powdery mildew $(P m)$ resistance genes Pml to Pm63 at 59 loci $(P m 18=P m 1 c, P m 22=$ Pmle, Pm23 = Pm4c, and Pm31 = Pm21) and $>20$ temporarily named Pm genes have been reported (Hao et al. 2015; Li et al. 2018; McIntosh et al. 2017; Sun et al. 2018; Tan et al. 2018; Zou et al. 2018). These genes are distributed on different wheat chromosomes, and most of them are race specific following Flor's gene-forgene concept (Flor 1971; McIntosh et al. 2013, 2017). Some of these gene loci, such as Pml (Hsam et al. 1998), Pm2 (Ma et al. 2015; Xu et al. 2015), Pm3 (Briggle 1966a, 1969; Sourdille et al. 1999; Zeller et al. 1993), Pm4 (Briggle 1966b; Hao et al. 2008; Schmolke et al. 2010; The et al. 1979), Pm5 (Hsam et al. 2001; Huang et al. 2003; Lebsock and Briggle 1974), Pm8/Pml7 (Hsam and Zeller 1997; Lukaszewski 2000), and Pm24 (Huang et al. 2000; Xue et al. 2012), have more than one resistance allele.

Although many $P m$ genes/alleles have been identified and named, not all identified resistance genes can be readily used in breeding programs. Many known powdery mildew resistance genes originated from rye (Secale cereale) and wheat's wild relatives, such as Aegilops tauschii, Triticum dicoccoides, Triticum timopheevii, and Haynaldia villosa. Breeders need to eliminate some adverse factors owing to linkage drag to use alien species-derived resistance and other desirable traits. It often takes many years for wheat breeders to eliminate the linkage drag of undesirable genes on alien chromosome segments (Klindworth et al. 2013; Summers and Brown 2013). So far, relatively few $P m$ resistance genes have been successfully utilized in developing powdery mildew-resistant wheat cultivars in China; these include Pm2a, Pm4a, Pm6, Pm8, and Pm21 (Gao et al. 2005; Huang et al. 2012; Li et al. 2011; Liu et al. 2000).

Molecular markers have been widely used for mapping $\mathrm{Pm}$ resistance genes in wheat (Alam et al. 2011; Fu et al. 2017; McIntosh et al. 2013; Petersen et al. 2015; Xiao et al. 2013; Xie et al. 2017; Xu et al. 2015, 2018). Diagnostic molecular markers that are tightly linked to $\mathrm{Pm}$ genes have contributed to the development of near-isogenic lines for powdery mildew resistance (Zhou et al. 2005) and markerassisted selection (MAS) for gene transfer and the pyramiding of 
resistance genes into released cultivars (Ma et al. 2018; Yildirim et al. 2004; Zhang et al. 2002). Furthermore, closely linked flanking markers have been useful for the map-based cloning of the resistance genes (Yahiaoui et al. 2004; Zou et al. 2018).

Chinese wheat landraces have been shown to be valuable genetic resources for crop improvement (Hazen et al. 2002; Ma et al. 2017). There are valuable resistance genes in the landraces, such as $P m 2 c$ in Niaomai (Xu et al. 2015), Pm5e in Fuzhuang 30 (Huang et al. 2003), Pm24a in Chiyacao (Huang et al. 2000), Pm24b in Baihulu (Xue et al. 2012), Pm47 in Hongyanglazi (Xiao et al. 2013), mlxbd in Xiaobaidong (Xue et al. 2009), $P m H$ in Hongquanmang (Zhou et al. 2005), $P m X$ in Xiaohongpi (Fu et al. 2013), MlHLT in Hulutou (Wang et al. 2015), PmT4 in Tangmai 4 (Xie et al. 2017), PmHYM in Hongyoumai (Fu et al. 2017), and PmSGD in Shangeda (Xu et al. 2018). More unidentified resistance genes likely are present in Chinese wheat landraces, which should be explored.

Chinese wheat landrace Dahongtou is highly resistant to powdery mildew in various wheat-growing regions (Zhao et al. 2012). The major objectives of this study were to identify and map the powdery mildew resistance gene(s) in Dahongtou, determine the relationship with previously reported alleles at the $P m 5$ locus on chromosome arm 7BL, and test tightly linked markers for their usefulness in MAS.

\section{Materials and Methods}

Plant materials. Chinese wheat landrace Dahongtou (S761) was provided by the National Crop Genebank of China (Beijing, China). $\mathrm{F}_{1}, \mathrm{~F}_{2}$, and $\mathrm{F}_{2: 3}$ seeds were obtained from the crosses of Dahongtou with the susceptible varieties Huixianhong $(\mathrm{HXH})$ and Mingxian 169 (MX169). When the resistance was tested at seedling stage in the greenhouse, $F_{1}$ and $F_{2}$ plants were inoculated using $B$. graminis f. sp. tritici isolate E09, representing the prevalent population in northern China (Li et al. 2011), and after recording the responses and removing sporulating leaves, the plants were transplanted into a field for the production of seeds of the next generation. The two segregating populations consisting of $208 \mathrm{~F}_{2}$ plants from the cross of $\mathrm{HXH} \times$ Dahongtou and $267 \mathrm{~F}_{2}$ plants from Dahongton $\times$ MX169 and their derived $\mathrm{F}_{2: 3}$ lines were used in the genetic analysis of powdery mildew resistance. Ten randomly selected homozygous-resistant $\mathrm{F}_{2: 3}$ lines from the cross of Dahongtou $\times$ MX169 were tested with 34 B. graminis $\mathrm{f}$. sp. tritici isolates that were avirulent to Dahongtou, not including the E09 isolate.

The common wheat cultivars/lines CI14125 (Pm5a), Aquila (Pm5b), Xiaobaidong ( $m l x b d)$, Hongyoumai (PmHYM), Fuzhuang $30(P m 5 e), \mathrm{HXH}$, and MX169 plus 178 wheat cultivars/lines (Supplementary Table S1) were used in this study. The isolates of B. graminis f. sp. tritici were preserved separately in culture tubes and multiplied on seedlings of MX169 before being used in the seedling tests for powdery mildew resistance.

Powdery mildew phenotyping. Dahongtou, HXH, MX169, and their $F_{1}, F_{2}$, and $F_{2: 3}$ progenies were evaluated for their powdery mildew reactions using $B$. graminis f. sp. tritici isolate E09. Thirty-eight single spore-derived B. graminis $\mathrm{f}$. sp. tritici isolates, including isolate E09, were used to compare the reaction patterns of Dahongtou and five wheat cultivars/lines with documented $P m$ genes on chromosome arm 7BL. Reactions of the plant materials to these B. graminis f. sp. tritici isolates were determined twice in the greenhouse. For each of the cultivars/lines, 20 seeds were sown in a 128-well (each well was $3 \mathrm{~cm}$ in length $\times 3 \mathrm{~cm}$ in width $\times 4.2 \mathrm{~cm}$ in height) rectangular tray (each tray was $54 \mathrm{~cm}$ in length $\times 28 \mathrm{~cm}$ in width $\times 4.2 \mathrm{~cm}$ in height) in a growth chamber; four seeds in four wells of the susceptible checks MX169 and HXH were also sown randomly in each tray. Seed of Dahongtou and five wheat cultivar/lines with documented $\mathrm{Pm}$ genes on chromosome 7BL were planted in 38 rectangular trays, which were tested separately for their reaction patterns against the $38 \mathrm{~B}$. graminis f. sp. tritici isolates. At the one-leaf stage (10 to 15 days old), all seedlings in a tray were inoculated with a single $B$. graminis $f$. sp. tritici isolate and then, maintained in a separate growth chamber in the greenhouse. All seedlings were inoculated with fresh spores that were multiplied on MX169 and incubated in a growth chamber at $18^{\circ} \mathrm{C}$ with a relative humidity $>80 \%$ for $24 \mathrm{~h}$; then, they were placed in the greenhouse with a diurnal cycle of $14 \mathrm{~h}$ of light at $22^{\circ} \mathrm{C}$ and $10 \mathrm{~h}$ of darkness at $18^{\circ} \mathrm{C}$ and a relative humidity $>80 \%$. Seedling reactions were recorded 8 to 10 days after inoculation when MX169 displayed heavy sporulation. The infection type (IT) on each plant was recorded on a 0 to 4 scale: IT 0,$0 ; 1$, and 2 were considered resistant, and IT 3 and 4 were susceptible (Sheng 1988; Wang et al. 2005).

Molecular marker linkage mapping. Total genomic DNA was extracted from wheat leaf tissues as previously described (Ma et al. 1994). DNA of resistant and susceptible bulks was prepared for bulk segregant analysis (Michelmore et al. 1991) by combining equal amounts of DNA from 10 resistant $(I T=0)$ or 10 susceptible $(I T=4)$ $\mathrm{F}_{2}$ plants from the cross of $\mathrm{HXH} \times$ Dahongtou.

Five hundred simple sequence repeat (SSR) markers that were evenly distributed across all of the wheat chromosomes (Somers et al. 2004) were selected for an initial screening for polymorphic markers. The SSR markers showing polymorphisms between the two bulks were used to genotype the $\mathrm{F}_{2}$ population. Based on their genomic location on the consensus linkage map, additional expressed sequence tag (EST)sequence tagged site (STS) markers in the target region of chromosome 7BL were designed and synthesized in the author's laboratory, and also, they were used to genotype the $\mathrm{F}_{2}$ population.

PCR was performed in a Veriti thermal cycler (Applied Biosystems) in a $10-\mu 1$ reaction mixture containing 10 to $20 \mathrm{ng}$ of template DNA, 2 pmol of each primer, $2 \mathrm{nmol}$ of each dNTP, $0.1 \mathrm{U}$ of Taq DNA polymerase, and $1 \times \mathrm{PCR}$ buffer $(50 \mathrm{mM} / \mathrm{liter} \mathrm{KCl}, 10 \mathrm{mM} /$ liter Tris- $\mathrm{HCl}$, and $1.5 \mathrm{mM} / \mathrm{liter} \mathrm{MgCl}_{2}$ ). The PCR profile included one cycle of $94^{\circ} \mathrm{C}$ for $3 \mathrm{~min}$ followed by 36 cycles of $94^{\circ} \mathrm{C}$ for 30 $\mathrm{s}, 50$ to $65^{\circ} \mathrm{C}$ (depending on the specific primers) for $40 \mathrm{~s}$, and $72^{\circ} \mathrm{C}$ for $40 \mathrm{~s}$ and a final extension at $72^{\circ} \mathrm{C}$ for $5 \mathrm{~min}$. PCR products were separated in $8 \%$ nondenaturing polyacrylamide gels with 19:1, $25: 1$, or 39:1 ratios of acrylamide and bis-acrylamide; then, they were silver stained and visualized as described by Santos et al. (1993).

In this study, $\chi^{2}$ tests for goodness of fit were used to evaluate deviations of observed phenotypic data from the expected segregation ratios of the $F_{2}$ and $F_{2: 3}$ generations. Software MAPMAKER/Exp (version 3.0b) was used to determine linkage using an LOD (logarithm of the odds) score of 3.0 as the threshold for declaration of linkage (Lander et al. 1987). Genetic distances were estimated from recombination values using the Kosambi mapping function (Kosambi 1943).

Physical mapping. DNA samples of the Chinese Spring nullitetrasomic (NT) lines (lacking one chromosome pair but compensated by the presence of an additional pair of homologous chromosomes) and ditelosomic lines (Dt; having 21 pairs of chromosomes but with one chromosome pair comprising only either the short or long arms) (Devos et al. 1999) were amplified with molecular markers to determine the chromosome arm locations of the target gene. Then, DNA samples of Chinese Spring deletion lines, in which one pair of chromosomes has different lengths of terminal deletions, were amplified with molecular markers to physically assign genes to small chromosomal regions (Qi et al. 2003).

As the powdery mildew resistance gene in Dahongtou, tentatively named $p m D H T$, was mapped to the long arm of chromosome 7B (7BL), molecular markers flanking the gene as well as other powdery mildew resistance genes previously identified on 7BL were used to genotype Chinese Spring and its five NT lines (N7AT7B, N7BT7A, N7BT7D, N7DT7A, and N7DT7B), two Dt lines (Dt7BS and Dt7BL), and seven 7BL deletion lines (7BS-1, 7BL-14, 7BL-2, 7BL-9, 7BL-7, $7 \mathrm{BL}-10$, and $7 \mathrm{BL}-3)$ to determine the chromosomal location of the markers and the resistance genes as described by Werner et al. (1992).

Allelism testing for determining the relationships of $\mathbf{p m D H T}$ with Pm5e and $\boldsymbol{m l x b d}$. Crosses were made between Dahongtou (pmDHT) and Fuzhuang 30 (Pm5e) and between Dahongtou and Xiaobaidong $(m l x b d)$, which carried the powdery mildew resistance genes on $7 \mathrm{BL} . \mathrm{F}_{1}$ and $\mathrm{F}_{2}$ plants of the crosses were tested with $\mathrm{B}$. graminis f. sp. tritici isolate $\mathrm{E} 09$, which was avirulent to resistance genes pmDHT, Pm5e, and mlxbd.

\section{Results}

Inheritance of the powdery mildew resistance in Dahongtou. When the parents and $F_{1}, F_{2}$, and $F_{2: 3}$ progeny populations from 
$\mathrm{HXH} \times$ Dahongtou and Dahongtou $\times$ MX169 were tested with B. graminis f. sp. tritici isolate E09 at the seedling stage, Dahongtou was nearly immune with an IT 0;, and both HXH and MX169 were susceptible with IT 4 (Table 1 ). The $\mathrm{F}_{1}$ plants were all susceptible with an IT 4. Among $267 \mathrm{~F}_{2}$ plants of the Dahongtou $\times$ MX169 cross, 64 were resistant with IT 0 to 2 , and 203 were susceptible with IT 3 to 4 , fitting a 1:3 ratio $\left(\chi^{2}=0.10, P=0.75\right)$ (Table 1$)$. Among the 267 $\mathrm{F}_{2: 3}$ lines of the Dahongtou $\times$ MX169 cross, 61 were homozygous resistant, 128 were segregating, and 78 lines were homozygous susceptible, fitting a $1: 2: 1$ segregation ratio $\left(\chi^{2}=2.62, P=0.27\right)$. Among $208 \mathrm{~F}_{2}$ plants of the $\mathrm{HXH} \times$ Dahongtou cross, 61 were resistant with IT 0 to 2 , and 147 were susceptible with IT 3 to 4 , fitting a 1: 3 ratio $\left(\chi^{2}=1.85, P=0.17\right)$. Among the $202 \mathrm{~F}_{2: 3}$ lines of $\mathrm{HXH} \times$
Dahongtou, 50 were homozygous resistant, 109 were segregating, and 43 were homozygous susceptible, fitting a 1:2:1 segregation ratio $\left(\chi^{2}=1.75, P=0.42\right)$. These results showed that the resistance of Dahongtou was conferred by a single recessive gene that was tentatively designated as $p m D H T$. When tested by the other $37 \mathrm{~B}$. graminis $f$. sp. tritici isolates, Dahongtou was susceptible to only 3 isolates (B45, B46, and B47), and therefore, Dahongtou with $p m D H T$ was resistant to 35 of 38 isolates, including E09 (Table 2). Ten randomly selected homozygous resistant $\mathrm{F}_{2: 3}$ lines from Dahongtou $\times$ MX169 were tested with the 34 isolates that were avirulent to Dahongtou; not including E09 isolate, all were homozygous resistant to all 34 isolates, showing that $\mathrm{pmDHT}$ conferred the resistance to all of the avirulent isolates.

Table 1. Inheritance of resistance to powdery mildew of the segregation populations derived from crosses of Dahongtou with Mingxian 169 (MX169) and Huixianhong $(\mathrm{HXH})$ and phenotypic reactions of the $\mathrm{F}_{2}$ populations from the crosses of Dahongtou with the documented resistance stocks Fuzhuang $30(P m 5 e)$ and Xiaobaidong $(m l x b d)$ to the Blumeria graminis $\mathrm{f}$. sp. tritici isolate E09. "R" means resistant to the powdery mildew with the infection type (IT) 0,0 ;, 1 and 2 . "S" means susceptible to the powdery mildew with IT 3 and 4.

\begin{tabular}{|c|c|c|c|c|c|c|c|}
\hline \multirow[b]{2}{*}{ Cross } & \multirow[b]{2}{*}{$\mathbf{F}_{1}$} & \multicolumn{3}{|c|}{$F_{2}$ populations } & \multicolumn{3}{|c|}{$\mathbf{F}_{2: 3}$ lines } \\
\hline & & $R: S$ & $\chi_{1: 3}^{2}$ & $P$ value & RR:Rr:rr & $\chi^{2} 1: 2: 1$ & $P$ value \\
\hline Dahongtou $\times$ MX169 & $\mathrm{S}$ & $64: 203$ & 0.10 & 0.75 & $61: 128: 78$ & 2.62 & 0.27 \\
\hline $\mathrm{HXH} \times$ Dahongtou & $\mathrm{S}$ & $61: 147$ & 1.85 & 0.17 & $50: 109: 43$ & 1.75 & 0.42 \\
\hline Dahongtou $\times$ Fuzhuang 30 & $\mathrm{R}$ & $1,078: 0$ & & & & & \\
\hline Dahongtou $\times$ Xiaobaidong & $\mathrm{R}$ & $1,672: 0$ & & & & & \\
\hline
\end{tabular}

Table 2. Seedling powdery mildew infection types of Dahongtou and genotypes carrying known Pm genes at the Pm5 loci after inoculation with 38 different Blumeria graminis f. sp. tritici (Bgt) isolates

\begin{tabular}{|c|c|c|c|c|c|c|c|c|}
\hline \multirow[b]{2}{*}{ Bgt isolates } & \multicolumn{8}{|c|}{ Cultivars/lines (Pm genes) } \\
\hline & Huixianhong & Mingxian 169 & $\begin{array}{c}\text { Dahongtou } \\
(p m D H T)\end{array}$ & $\begin{array}{c}\text { CI14125 } \\
(\text { Pm5a) }\end{array}$ & $\begin{array}{l}\text { Aquila } \\
(\text { Pm5b) }\end{array}$ & $\begin{array}{c}\text { Fuzhuang } 30 \\
(P m 5 e)\end{array}$ & $\begin{array}{c}\text { Xiaobaidong } \\
(m l x b d)\end{array}$ & $\begin{array}{c}\text { Hongyoumai } \\
(\text { PmHYM })\end{array}$ \\
\hline$\overline{\mathrm{E} 03}$ & 4 & 4 & 0 & 4 & 4 & 0 & 0 & 0 \\
\hline E05 & 4 & 4 & 0 & 4 & 4 & 0 & 0 & 0 \\
\hline E06 & 4 & 4 & 0 & 4 & 4 & 0 & 0 & 0 \\
\hline E09 & 4 & 4 & 0 & 4 & 4 & 0 & 0 & 0 \\
\hline E11 & 4 & 4 & 0 & 4 & 4 & 0 & 0 & 0 \\
\hline E13 & 4 & 4 & 0 & 4 & 4 & 0 & 0 & 0 \\
\hline E16 & 4 & 4 & 0 & 4 & 4 & 0 & 0 & 0 \\
\hline E17 & 4 & 4 & 0 & 4 & 4 & 0 & 0 & 0 \\
\hline E18 & 4 & 4 & 0 & 4 & 4 & 0 & 0 & 0 \\
\hline E21 & 4 & 4 & 0 & 4 & 4 & 0 & 0 & 0 \\
\hline E22 & 4 & 4 & 0 & 4 & 4 & 0 & 0 & 0 \\
\hline E23-1 & 4 & 4 & 0 & 4 & 4 & 0 & 0 & 3 \\
\hline E23-2 & 4 & 4 & 0 & 4 & 4 & 0 & 0 & 0 \\
\hline E26 & 4 & 4 & 0 & 4 & 4 & 0 & 0 & 0 \\
\hline E30-2 & 4 & 4 & 0 & 4 & 2 & 0 & 1 & 0 \\
\hline E31 & 4 & 4 & 0 & 4 & 4 & 0 & 0 & 0 \\
\hline E32 & 4 & 4 & 0 & 4 & 4 & 0 & 0 & 0 \\
\hline E49 & 4 & 4 & 0 & 4 & 0 & 4 & 4 & 0 \\
\hline E50 & 4 & 4 & 0 & 4 & 0 & 4 & 0 & 0 \\
\hline B13 & 4 & 4 & 0 & 4 & 4 & 0 & 0 & 0 \\
\hline B14 & 4 & 4 & 0 & 4 & 4 & 0 & 0 & 0 \\
\hline B15 & 4 & 4 & 0 & 4 & 4 & 4 & 0 & 0 \\
\hline B16 & 4 & 4 & 0 & 4 & 2 & 3 & 3 & 0 \\
\hline B17 & 4 & 4 & 0 & 4 & 4 & 0 & 0 & 0 \\
\hline B41 & 4 & 4 & 0 & 4 & 0 & 0 & 0 & 0 \\
\hline B42 & 4 & 4 & 0 & 4 & 4 & 0 & 0 & 0 \\
\hline B43 & 4 & 4 & 0 & 4 & 4 & 0 & 0 & 0 \\
\hline B44 & 4 & 4 & 0 & 4 & 4 & 0 & 0 & 0 \\
\hline B45 & 4 & 4 & 3 & 4 & 4 & 0 & 0 & 0 \\
\hline B46 & 4 & 4 & 3 & 4 & 4 & 0 & 0 & 0 \\
\hline B47 & 4 & 4 & 4 & 4 & 4 & 3 & 4 & 4 \\
\hline B48 & 4 & 4 & 0 & 4 & 4 & 0 & 0 & 0 \\
\hline B49 & 4 & 4 & 0 & 4 & 4 & 0 & 0 & 0 \\
\hline B54 & 4 & 4 & 0 & 4 & 4 & 0 & 0 & 0 \\
\hline B55 & 4 & 4 & 0 & 4 & 4 & 0 & 0 & 0 \\
\hline B56 & 4 & 4 & 0 & 4 & 4 & 0 & 0 & 0 \\
\hline B57 & 4 & 4 & 0 & 4 & 4 & 0 & 0 & 0 \\
\hline B58 & 4 & 4 & 0 & 4 & 4 & 0 & 0 & 0 \\
\hline
\end{tabular}


Genetic mapping of pmDHT. In the initial screening of SSR markers for polymorphisms between Dahongtou and HXH and the DNA bulks with 500 SSR markers, only 4 markers on chromosome $7 \mathrm{~B}$ were consistently polymorphic between the parents and between the resistant and susceptible bulks. However, these four polymorphic markers were not closely linked to $p m D H T$. An additional 76 markers previously mapped on chromosome arm 7BL were tested, and 9 of them (Xwmc311, Xbarc32,Xwmc526, Xgwm611, Xcfa2040, Xwmc581, Xwmc273, Xwmc276, and Xgwm577) were polymorphic. All $208 \mathrm{~F}_{2}$ plants from $\mathrm{HXH} \times$ Dahongtou were genotyped with the nine markers. A genetic linkage map was constructed with the markers, and $p m D H T$ was positioned $0.8 \mathrm{cM}$ proximal to $X w m c 526$

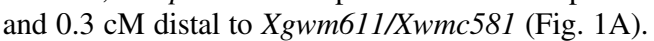

Because these markers are located in the physical region 0.86 to 1.00 of 7BL (https://wheat.pw.usda.gov/GG3/), pmDHT must be located in this chromosomal bin. The sequences of 146 ESTs in this region were used to develop EST-STS markers, and those markers were tested on the two parents, the DNA bulks, and the 208 plants of $\mathrm{F}_{2}$ population. The primer sequences of the two polymorphic markers $X B E 443877$ and XBF473539, which are listed in Table 3, flanked the resistance locus at genetic distances of 0.8 and $1.2 \mathrm{cM}$, respectively (Fig. 1A). pmDHT was flanked by Xwmc526/ XBE443877 and Xgwm611/Xwmc581 at genetic distances of 0.8 and $0.3 \mathrm{cM}$, respectively (Fig. 1A) and located on chromosome $7 \mathrm{BL}$ at a position at or near the Pm5 locus. According to the molecular markers from the linkage map, the genetic distances of Xgwm611 and Xgwm577 from pmDHT were different from those for Pm5d, Pm5e, mlxbd, and PmHYM (Fig. 2).

Physical mapping of $\mathbf{p m D H T}$. To determine the physical position of $p m D H T$, the SSR and EST-STS markers linked to $p m D H T$ and assigned to the 0.86 to 1.00 terminal bin of 7BL based on Nematollahi et al. (2008) were tested with DNA samples of Chinese Spring and its five NT lines (N7AT7B, N7BT7A, N7BT7D, N7DT7A, and N7DT7B), two Dt lines (DT7BS and DT7BL), and seven deletion lines (7BS-1, 7BL-14, 7BL-2, 7BL-9, 7BL-7, 7BL-10, and 7BL-3). All of the 14 lines tested indicated that marker loci were

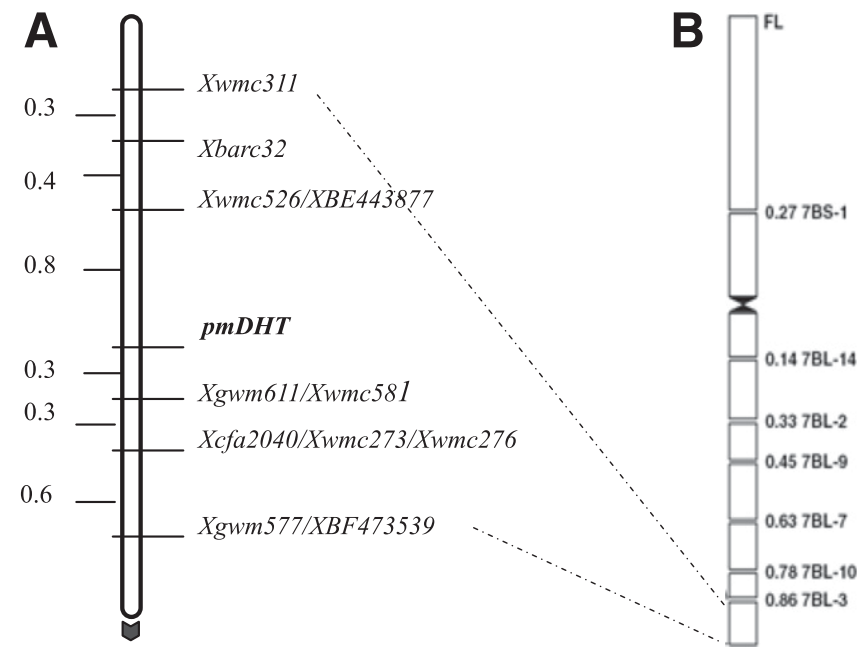

Fig. 1. Linkage map of $p m D H T$. A, Linkage map of pmDHTon chromosome arm 7BL. The black arrow points to the centromere, and genetic distances are shown on the left in centimorgans. B, Bin assignments of pmDHT-linked markers are shown with dashed line connections and breakpoints, and fraction lengths $(F L)$ of the bins are shown to the right. missing in the N7BT7A, N7BT7D, DT7BS, 7BS-1, 7BL-14, 7BL2, 7BL-9, 7BL-7, and 7BL-10, whereas marker loci were detected in the N7AT7B, N7DT7A, N7DT7B, DT7BL, and 7BL-3. Thus, pmDHT was mapped to the 7BL-3 chromosomal bin (0.86 to 1.00$)$ (Fig. 1B).

Allelic relationship and resistance spectra. In the cross of Dahongtou $\times$ Fuzhuang 30 , all $6 \mathrm{~F}_{1}$ and $1,078 \mathrm{~F}_{2}$ plants were resistant (Table 1). Similarly, all $8 \mathrm{~F}_{1}$ and the $1,672 \mathrm{~F}_{2}$ plants from Dahongtou $\times$ Xiaobaidong were also resistant. These results indicated that the pmDHT, Pm5e, and $m l x b d$ were allelic or tightly linked.

Thirty-eight different B. graminis $f$. sp. tritici isolates (Table 2) were used to compare the reaction patterns of Dahongtou with wheat lines possessing resistance genes Pm5a,Pm5b, Pm5e, mlxbd, or PmHYM on chromosome arm 7BL. Both Dahongtou with $p m D H T$ and Xiaobaidong with $m l x b d$ were resistant to 35 of the tested 38 isolates but not the same 35 isolates (Fig. 3 and Table 2). Hongyoumai with PmHYM was resistant to 36 isolates, Fuzhuang 30 with Pm5e was resistant to 33 isolates, and Aquila with $P m 5 b$ was resistant to five isolates, whereas CI14125 with Pm5a was susceptible to all 38 isolates (Table 2). Comparing the reaction pattern of $p m D H T$ with PmSGD (Xu et al. 2018), among the 11 isolates (E05, E06, E09, E13, E17, E18, E23-1, E23-2, E32, E49, and E50), Dahongtou was resistant to all of them, whereas Shangeda with PmSGD was resistant to 10 and susceptible to isolate E17 (Xu et al. 2018). Thus, the reaction pattern of $p m D H T$ was different from those of Pm5a, Pm5b, Pm5e, $m l x b d, P m H Y M$, and PmSGD, which are located at or near the Pm5 locus, and therefore, $p m D H T$ should be a new allele of the Pm5 locus.

Molecular variability and validation of closely linked markers flanking $\mathbf{p m D H T}$. The markers flanking $p m D H T$ were used to test five wheat lines CI14125 (Pm5a), Aquila (Pm5b), Fuzhuang 30 (Pm5e), Xiaobaidong ( $m l x b d)$, and Hongyoumai (PmHYM), which were reported to carry different $P m 5$ resistance alleles, and the 178 common wheat cultivars/lines (Fig. 1). The EST-STS marker XBE443877 and the SSR marker Xwmc526 amplified bands of 406 and 188 bp, respectively, in Dahongtou, Aquila, Fuzhuang 30, Xiaobaidong, and Hongyoumai but not in CI14125. The same bands appeared in 61 and 63 of 178 cultivars/lines, respectively, but not in the other cultivars/lines. The marker Xwmc581 amplified a band of 136 bp in Dahongtou, Fuzhuang 30, and 76 of 178 cultivars/ lines but not in CI14125, Aquila, Xiaobaidong, Hongyoumai, or the other 102 cultivars/lines. The marker Xgwm611 amplified bands of $166 \mathrm{bp}$ in Dahongtou but not in the five wheat lines with $P m 5$ resistance alleles Pm5a, Pm5b, Pm5e, mlxbd, and PmHYM or the 178 cultivars/lines tested.

The markers XBE443877 and Xwmc526 could be used to distinguish $p m D H T$ from $P m 5 a$ but could not distinguish $p m D H T$ from Pm5b, Pm5e, mlxbd, and PmHYM. Xwmc581 could be used to distinguish pmDHT from $P m 5 a, P m 5 b, m l x b d$, and PmHYM but could not distinguish pmDHT from Pm5e. Xgwm611 could be used to distinguish pmDHT from Pm5a, Pm5b, Pm5e, mlxbd, and PmHYM, and it could also be used as a diagnostic marker for detecting $p m D H T$ in the different genomic backgrounds for MAS.

\section{Discussion}

Because wheat powdery mildew has become increasingly important and several resistance genes have become ineffective (He et al. 2018; Li et al. 2011; Xing et al. 2018; Zhao et al. 2013; Zhuang and $\mathrm{Li}$ 1993), there is an urgent need to identify new effective resistance genes or alleles to develop cultivars with long-lasting resistance through gene pyramiding. In this study, a new recessive gene for resistance to powdery mildew, tentatively named $p m D H T$, was

Table 3. Sequence information of polymorphic expressed sequence tag-sequence tagged site (EST-STS) markers on chromosome arm 7BL used in the Dahongtou resistance gene mapping

\begin{tabular}{lclc}
\hline EST-STS marker & Chromosome & Forward sequence $\left(\mathbf{5}^{\prime} \mathbf{-} \mathbf{3}^{\prime}\right)$ & Reverse sequence $\left(\mathbf{5}^{\prime} \mathbf{-} \mathbf{3}^{\prime}\right)$ \\
\hline$X B E 443877$ & $7 \mathrm{BL}$ & GTAGCACCAAGCACTATTT & AAGCATTTGACATCTCCC \\
$X B F 473539$ & 7BL & GGATGGGATGCTGTCTTT & TGTGGTTCAGTCGGTGTAG \\
\hline
\end{tabular}


identified in the Chinese wheat landrace Dahongtou. Tests in this study have shown that this gene confers a broad spectrum of resistance against $B$. graminis $f$. sp. tritici isolates. Therefore, this gene would be useful to pyramid with other effective $P m$ genes to develop new cultivars with high-level and long-lasting resistance to powdery mildew.

Resistance gene $p m D H T$ was mapped in the terminal region of chromosome arm 7BL. To data, several $P m$ genes, including Pm5 (a-e), mlxbd, PmTm4, PmHYM, and PmSGD, have been mapped on 7BL. The results of this study indicate that $p m D H T, P m 5 e$, and $m l x b d$ are allelic, and the resistance spectrum of $p m D H T$ is different from those of Pm5a, Pm5b, Pm5e, mlxbd, PmHYM, and PmSGD. Genetic analysis indicated that the resistance of Dahongtou to $B$. graminis $f$. sp. tritici isolate $\mathrm{E} 09$ was conferred by the recessive gene $p m D H T$, and therefore, pmDHT is different from PmT4, because PmT4 was reported as a semidominant gene (Hu et al. 2008; Xie et al. 2017). Kolandi was a Triticum sphaeroccum-derived wheat line
(ATRI 2996/74) from India, and it carried Pm5c. IGV1-455 (CI10904/7*Prins) and IGV1-556 (CI10904/7*Starke) were the Kolandi backcross-derived wheat lines, and they also carried Pm5d (Hsam et al. 2001; Nematollahi et al. 2008). Based on the genetic backgrounds of these wheat lines, $p m D H T$ identified in this study is genetically distant from $P m 5 c$ and $P m 5 d$.

The genetic distances of Xgwm611 and Xgwm577 from pmDHT were different from those from Pm5d, Pm5e, PmHYM, and mlxbd according to the molecular markers on the linkage map (Fig. 2). The sequences of all 17 single-nucleotide polymorphism markers for PmSGD (Xu et al. 2018) were BLAST searched against the genomic sequence of Chinese Spring (https://urgi.versailles.inra.fr/blast_ iwgsc/blast.php). All of them were located in the range of 700.4 to $739.6 \mathrm{Mb}$ and overlapped with $p m D H T$ marker sequences of Xwmc311, Xbarc32, Xwmc581, Xcfa2040, Xwmc273, Xwmc276, and $X B E 443877$, which were located in the 690.9- to $734.9-\mathrm{Mb}$ regions. The comparison of the molecular markers suggests that
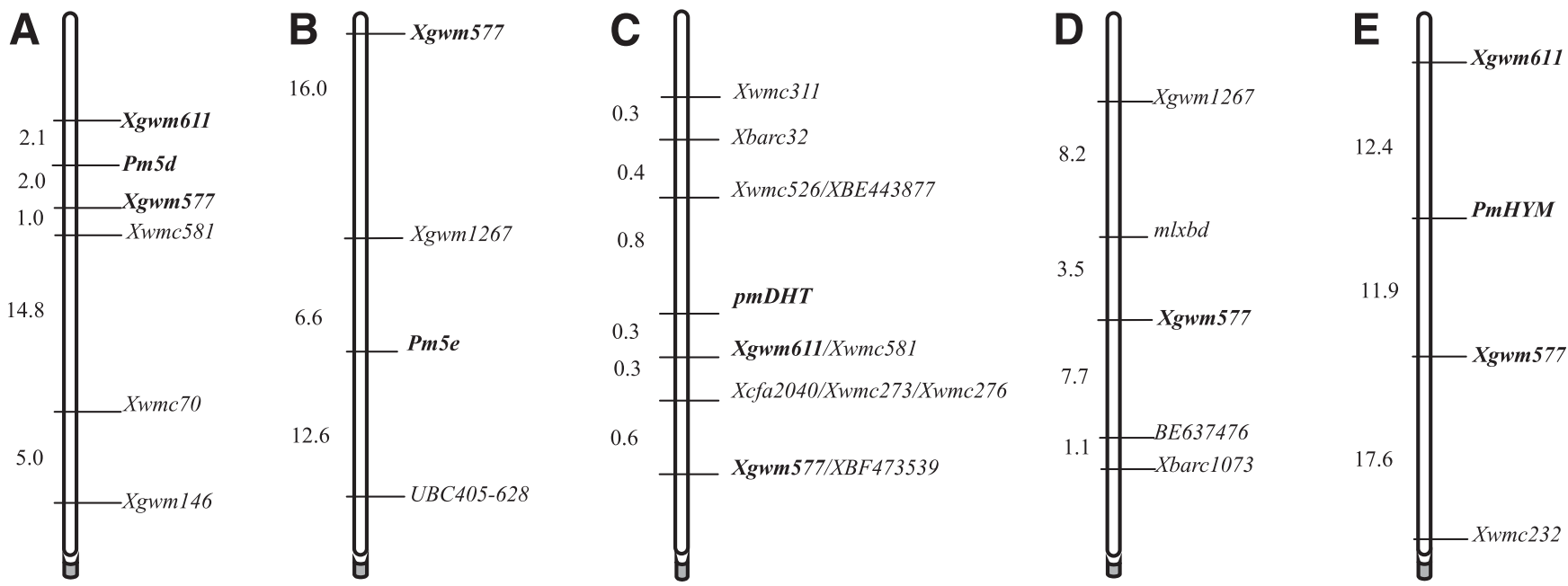

Fig. 2. Comparison of molecular markers linked to genes $P m 5 d(\mathbf{A}), \operatorname{Pm} 5 e(\mathbf{B}), \operatorname{pmDHT}(\mathbf{C}), m / x b d(\mathbf{D})$, and PmHYM (E) on chromosome arm 7BL.

\section{Huixianhong (susceptible CK)}

B15

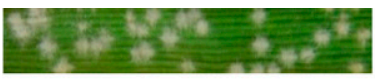

B16

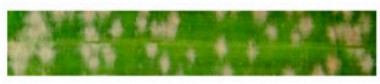

E06

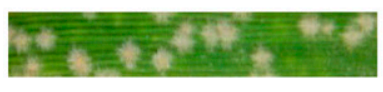

E49

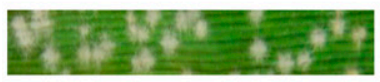

E50
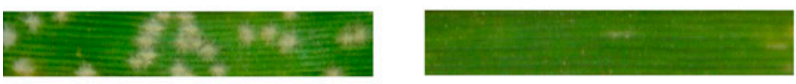

Dahongtou

$(p m D H T)$
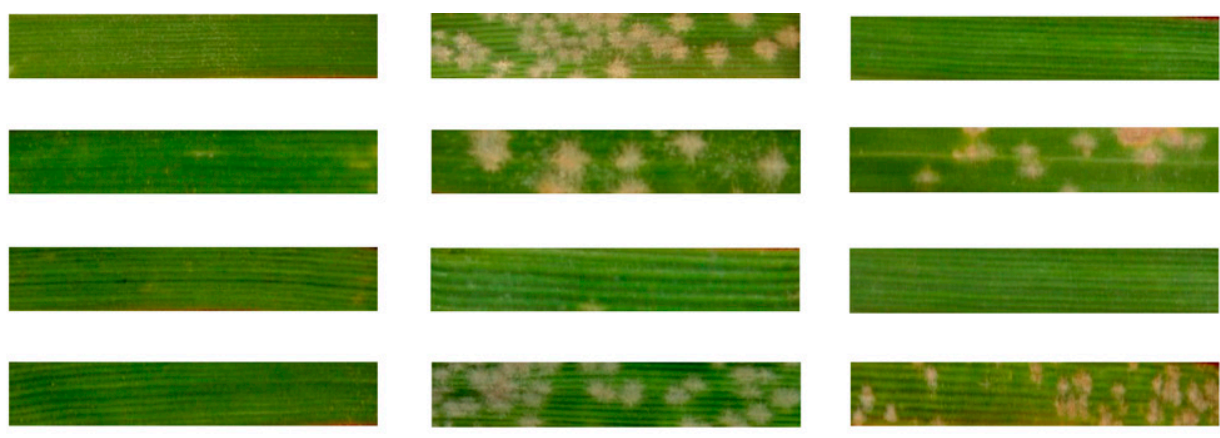

Fuzhuang 30

(Pm5e)

\section{Xiaobaidong $(m l x b d)$}
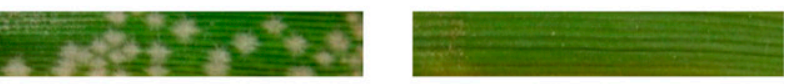

B45
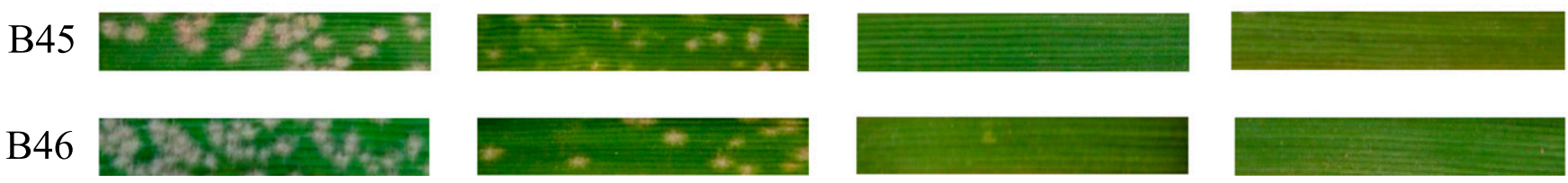

Fig. 3. Seedling reactions of Dahongtou, Fuzhuang $30(P m 5 e)$, Xiaobaidong $(\mathrm{m} / \mathrm{xbd})$, and Huixianhong (susceptible check) after inoculation with seven different isolates of Blumeria graminis f. sp. tritici. 
pmDHT is likely different from Pm5d, Pm5e, mlxbd, and PmHYM, whereas $p m D H T$ and $P m S G D$ overlap in the same genomic region; however, they are different alleles, because these two $P m$ genes possessed different reaction patterns to $B$. graminis $f$. sp. tritici isolates.

Some $P m$ genes from Chinese wheat landraces, such as Pm5e in Fuzhuang 30 (Huang et al. 2003), $\mathrm{PmH}$ in Hongquanmang (Zhou et al. 2005), mlxbd in Xiaobaidong (Xue et al. 2009), Pm47 in Hongyanglazi (Xiao et al. 2013), $P m X$ in Xiaohongpi (Fu et al. 2013), PmHYM in Hongyoumai (Fu et al. 2017), and PmSGD in Shangeda (Xu et al. 2018), were previously reported as recessive genes. Although studies have been conducted to determine the mechanisms controlling the dominant or recessive nature of the genes (Frye et al. 2001; Nishimura et al. 2003), the mechanisms controlling recessive powdery mildew resistance genes in Chinese wheat landraces are still unknown. Additional studies are needed to determine the resistance mechanisms, especially for the alleles at the Pm5 locus.

In this study, $p m D H T$ was identified and mapped as a new allele of the Pm5 locus or a tightly linked gene with Pm5 in the Chinese wheat landrace Dahongtou. pmDHT provides a broad spectrum of resistance to different virulent $B$. graminis $f$. $s p$. tritici isolates from China. This gene can be transferred into susceptible wheat cultivars/lines or combined with other effective resistance genes through MAS, which would be useful for improving powdery mildew resistance. There are several alleles at the $P m 5$ locus, especially in the Chinese wheat landraces. Fine mapping to develop a highdensity genetic linkage map for $p m D H T$ would be beneficial for the further characterization of the allelic variation at $P m 5$ locus. Such information and genetic resources should be useful for wheat scientists to study and develop new wheat cultivars with durable resistance to powdery mildew.

\section{Acknowledgments}

We thank Dr. Xianming Chen (U.S. Department of Agriculture-Agricultural Research Service and Washington State University) for critically reviewing the manuscript. Thanks are also extended to Prof. Yilin Zhou (Institute of Plant Protection, Chinese Academy of Agricultural Sciences) and Prof. Zhengqiang Ma (Nangjing Agricultural University) for providing the isolates of Blumeria graminis f. sp. tritici; Prof. Hongyan Liu (Institute of Plant Protection, Henan Academy of Agricultural Sciences) for providing seeds of wheat cultivars/lines CI14125 (Pm5a), Aquila $(P m 5 b)$, Xiaobaidong $(m l x b d)$, and Hongyoumai (PmHYM); Prof. Hongjie Li (Institute of Crop Science, Chinese Academy of Agricultural Sciences) for seeds of Fuzhuang 30 (Pm5e); and Prof. Zhengqiang Ma (Nanjing Agricultural University) for all nullitetrasomic lines, ditelosomic lines, and deletion lines of Chinese Spring.

\section{Literature Cited}

Alam, M. A., Xue, F., Wang, C. Y., and Ji, W. Q. 2011. Powdery mildew resistance genes in wheat: Identification and genetic analysis. J. Mol. Biol. Res. 1:20-39.

Bennett, F. G. A. 1984. Resistance to powdery mildew in wheat: A review of its use in agriculture and breeding programmes. Plant Pathol. 33:279-300.

Bliffeld, M., Mundy, J., Potrykus, I., and Futterer, J. 1999. Genetic engineering of wheat for increased resistance to powdery mildew disease. Theor. Appl. Genet. 98:1079-1086.

Briggle, L. W. 1966a. Three loci in wheat involving resistance to Erysiphe graminis f. sp. tritici. Crop Sci. 6:461-465.

Briggle, L. W. 1966b. Transfer of resistance to Erysiphe graminis f. sp. tritici from Khapli emmer and Yuma durum to hexaploid wheat. Crop Sci. 6:459-461.

Briggle, L. W. 1969. Near-isogenic lines of wheat with genes for resistance to Erysiphe graminis f. sp. tritici. Crop Sci. 9:70-72.

Deising, H. B., Reimann, S., Peil, A., and Weber, W. E. 2002. Disease management of rusts and powdery mildews. Pages 243-269 in: Agricultural Applications. The Mycota (A Comprehensive Treatise on Fungi as Experimental Systems for Basic and Applied Research), Vol. 11. F. Kempken, ed. Springer, Heidelberg, Germany.

Devos, K. M., Sorrells, M. E., and Anderson, J. A. 1999. Chromosome aberrations in wheat nullisomic- tetrasomic and ditelosomic line. Cereal Res. Commun. 27: 231-239.

Flor, H. H. 1971. Current status of the gene for gene concept. Annu. Rev. Phytopathol. 9:275-296.

Frye, C. A., Tang, D., and Innes, R. W. 2001. Negative regulation of defense responses in plants by a conserved MAPKK kinase. Proc. Natl. Acad. Sci. USA 98:373-378.

Fu, B. S., Chen, Y., Li, N., Ma, H. Q., Kong, Z. X., Zhang, L. X., Jia, H. Y., and Ma, Z. Q. 2013. PmX: A recessive powdery mildew resistance gene at the Pm4 locus identified in wheat landrace Xiaohongpi. Theor. Appl. Genet. 126:913-921.
Fu, B. S., Zhang, Z. L., Zhang, Q. F., Wu, X. Y., Wu, J. Z., and Cai, S. B. 2017. Identification and mapping of a new powdery mildew resistance allele in the Chinese wheat landrace Hongyoumai. Mol. Breed. 37:133.

Gao, A., He, H., and Chen, Q. 2005. Pyramiding wheat powdery mildew resistance genes Pm2, Pm4a, and Pm21 by molecular marker-assisted selection. Acta Agron. Sin. 11:1400-1405.

Hao, Y. F., Liu, A. F., Wang, Y. H., Feng, D. S., Gao, J. R., Li, X. F., Liu, S. B., and Wang, H. G. 2008. Pm23: A new allele of Pm4 located on chromosome 2AL in wheat. Theor. Appl. Genet. 117:1205-1212.

Hao, Y. F., Parks, R., Cowger, C., Chen, Z. B., Wang, Y. Y., Bland, D., Murphy, P., Guedira, M., Brown-Guedira, G., and Johnson, J. 2015. Molecular characterization of a new powdery mildew resistance gene Pm54 in soft red winter wheat. Theor. Appl. Genet. 128:465-476.

Hazen, S. P., Zhu, L., Kim, H. S., Tang, G. S., and Ward, R. W. 2002. Genetic diversity of winter wheat in Shaanxi province, China, and other common wheat germplasm pools. Genet. Resour. Crop Evol. 49:439-448.

He, H. G., Zhu, S. Y., Zhao, R. H., Jiang, A. N., Ji, Y. Y., Ji, J., Qiu, D., Li, H. J., and Bie, T. D. 2018. Pm21, encoding a typical CC-NBS-LRR protein, confers broad-spectrum resistance to wheat powdery mildew disease. Mol. Plant 11: 879-882.

Hsam, S. L. K., Huang, X. Q., Ernst, F., Hartl, L., and Zeller, F. J. 1998 Chromosomal location of genes for resistance to powdery mildew in common wheat (Triticum aestivum L. em Thell.). 5. Alleles at the Pml locus. Theor. Appl. Genet. 96:1129-1134.

Hsam, S. L. K., Huang, X. Q., and Zeller, F. J. 2001. Chromosomal location of genes for resistance to powdery mildew in common wheat (Triticum aestivum L. em. Thell.) 6. Alleles at the Pm5 locus. Theor. Appl. Genet. 102:127-133.

Hsam, S. L. K., and Zeller, F. J. 1997. Evidence of allellism between genes Pm8 and Pm17 and chromosomal location of powdery mildew and leaf rust resistance genes in the common wheat cultivar 'Amigo'. Plant Breed. 116: 119-122.

Hu, T. Z., Li, H. J., Xie, C. J., You, M. S., Yang, Z. M., Sun, Q. X., and Liu, Z. Y. 2008. Molecular mapping and chromosomal location of powdery mildew resistance gene in wheat cultivar Tangmai 4. Acta Agron. Sin. 34:1193-1198.

Huang, J., Zhao, Z. H., Song, F. J., Wang, X. M., Xu, H. X., Huang, Y., An, D. G., and Li, G. J. 2012. Molecular detection of a gene effective against powdery mildew in the wheat cultivar Liangxing 66. Mol. Breed. 30:1737-1745.

Huang, X. Q., Hsam, S. L. K., Zeller, F. J., Wenzel, G., and Mohler, V. 2000 Molecular mapping of the wheat powdery mildew resistance gene Pm24 and marker validation for molecular breeding. Theor. Appl. Genet. 101:407-414.

Huang, X. Q., Wang, L. X., Xu, M., and Roder, M. S. 2003. Microsatellite mapping of the powdery mildew resistance gene Pm5e in common wheat (Triticum aestivum L.). Theor. Appl. Genet. 106:858-865.

Johnson, J., Baenziger, P., Yamazaki, W., and Smith, R. 1979. Effects of powdery mildew on yield and quality of isogenic lines of 'Chancellor' wheat. Crop Sci. 19:349-352.

Klindworth, D. L., Hareland, G. A., Elias, E. M., and Xu, S. S. 2013. Attempted compensation for linkage drag affecting agronomic characteristics of durum wheat 1AS/1DL translocation lines. Crop Sci. 53:422-429.

Kosambi, D. D. 1943. The estimation of map distances from recombination values. Ann. Eugen. 12:172-175.

Lander, E. S., Green, P., Abrahamson, J., Barlow, A., Daly, M. J., Lincoln, S. E., and Newberg, L. A. 1987. MAPMAKER: An interactive computer package for constructing primary genetic linkage maps of experimental and natural populations. Genomics 1:174-181

Lebsock, K. L., and Briggle, L. W. 1974. Gene Pm5 for resistance to Erysiphe graminis f. sp. tritici in Hope wheat. Crop Sci. 14:561-563.

Li, G. Q., Carver, B. F., Cowger, C., Bai, G. H., and Xu, X. Y. 2018. Pm223899, a new recessive powdery mildew resistance gene identified in Afghanistan landrace PI 223899. Theor. Appl. Genet. 131:2775-2783.

Li, H. J., Wang, X. M., Song, F. J., Wu, C. P., Wu, X. F., Zhang, N., Zhou, Y., and Zhang, X. Y. 2011. Response to powdery mildew and detection of resistance genes in wheat cultivars from China. Acta Agron. Sin. 37:943-954.

Liu, J., Liu, D., Tao, W., Li, W., Wang, S., Chen, P., Cheng, S., and Gao, D. 2000. Molecular marker-facilitated pyramiding of different genes for powdery mildew resistance in wheat. Plant Breed. 119:21-24.

Lukaszewski, A. J. 2000. Manipulation of the 1RS·1BL translocation in wheat by induced homoeologous recombination. Crop Sci. 40:216-225.

Ma, P. T., Xu, H. X., Xu, Y. F., Li, L. H., Qie, Y. M., Luo, Q. L., Zhang, X. T., Li X. Q., Zhou, Y. L., and An, D. G. 2015. Molecular mapping of a new powdery mildew resistance gene Pm $2 b$ in Chinese breeding line KM2939. Theor. Appl. Genet. 128:613-622.

Ma, P. T., Xu, H. X., Xu, Y. F., Song, L. P., Liang, S. S., Sheng, Y., Han, G. H., Zhang, X. T., and An, D. G. 2018. Characterization of a powdery mildew resistance gene in wheat breeding line $10 \mathrm{~V}-2$ and its application in markerassisted selection. Plant Dis. 102:925-931.

Ma, X. L., Sajjad, M., Wang, J., Yang, W. L., Sun, J. Z., Li, X., Zhang, A. M., and Liu, D. C. 2017. Diversity, distribution of puroindoline genes and their effect on kernel hardness in a diverse panel of Chinese wheat germplasm. BMC Plant Biol. 17:158.

Ma, Z. Q., Sorrells, M. E., and Tanksley, S. D. 1994. RFLP markers linked to powdery mildew resistance genes $P m 1, P m 2, P m 3$, and $P m 4$ in wheat Genome 37:871-875. 
McDonald, B. A., and Linde, C. 2002. Pathogen population genetics, evolution potential and durable resistance. Annu. Rev. Phytopathol. 40:349-379.

McIntosh, R. A., Dubcovsky, J., Rogers, W. J., Morris, C., and Xia, X. C. 2017. Catalogue of Gene Symbols for Wheat: Supplement. https://shigen.nig.ac.jp/ wheat/komugi/genes/macgene/supplement2017.pdf

McIntosh, R. A., Yamazaki, Y., Dubcovsky, J., Rogers, W. J., Morris, C., Appels, R., and Xia, X. C. 2013. Catalogue of Gene Symbols for Wheat: $12^{\text {th }}$ International Wheat Genetic Symposium, Yokohama, Japan. https://shigen.nig.ac.jp/wheat/ komugi/genes/download.jsp

Michelmore, R. W., Paran, I., and Kesseli, R. V. 1991. Identification of markers linked to disease-resistance genes by bulked segregant analysis: A rapid method to detect markers in specific genomic regions by using segregating populations. Proc. Natl. Acad. Sci. USA 88:9828-9832.

Morgounov, A., Tufan, H. A., Sharma, R., Akin, B., Bagci, A., Braun, H., Kaya, Y., Keser, M., Payne, T. S., Sonder, K., and McIntosh, R. 2012. Global incidence of wheat rusts and powdery mildew during 1969-2010 and durability of resistance of winter wheat variety Bezostaya 1. Eur. J. Plant Pathol. 132:323-340

Nematollahi, G., Mohler, V., Wenzel, G., Zeller, F. J., and Hsam, S. L. K. 2008. Microsatellite mapping of powdery mildew resistance allele Pm5d from common wheat line IGV1-455. Euphytica 159:307-313

Nishimura, M. T., Stein, M., Hou, B. H., Vogel, J. P., Edwards, H., and Somerville, S. C. 2003. Loss of a callose synthase results in salicylic acid dependent disease resistance. Science 301:969-972.

Petersen, S., Lyerly, J. H., Worthington, M. L., Parks, W. R., Cowger, C., Marshall, D. S., Brown-Guedira, G., and Murphy, P. J. 2015. Mapping of powdery mildew resistance gene Pm53 introgressed from Aegilops speltoides into soft red winter wheat. Theor. Appl. Genet. 128:303-312.

Qi, L. L., Echalier, B., Friebe, B., and Gill, B. S. 2003. Molecular characterization of a set of wheat deletion stocks for use in chromosome bin mapping of ESTs. Funct. Integr. Genomics 3:39-55.

Santos, F. R., Pena, S. D., and Epplen, J. T. 1993. Genetic and population study of a Y-linked tetranucleotide repeat DNA polymorphism with a simple non-isotopic technique. Hum. Genet. 90:655-656.

Schmolke, M., Mohler, V., Hartl, L., Zeller, F. J., and Hsam, S. L. K. 2010. A new powdery mildew resistance allele at the Pm4 locus from einkorn (Triticum monococcum). Mol. Breed. 29:449-456.

Sheng, B. Q. 1988. Wheat powdery mildew was recorded using infection type in seedling stage. Plant Prot. 14:49.

Somers, D. J., Isaac, P., and Edwards, K. 2004. A high-density microsatellite consensus map for bread wheat (Triticum aestivum L.). Theor. Appl. Genet. 109:1105-1114.

Sourdille, P., Robe, P., Tixier, M. H., Doussinault, G., Pavoine, M. T., and Bernard, M. 1999. Location of Pm3g, a powdery mildew resistance allele in wheat, by using a monosomic analysis and by identifying associated molecular markers. Euphytica 110:193-198.

Summers, R. W., and Brown, J. K. M. 2013. Constraints on breeding for disease resistance in commercially competitive wheat cultivars. Plant Phothol. 62 (Suppl. 1):115-121.

Sun, H. G., Hu, J. H., Song, W., Qiu, D., Cui, L., Wu, P. P., Zhang, H. J., Liu, H. W., Yang, L., Qu, Y. F., Li, Y. H., Li, T., Cheng, W., Zhou, Y., Liu, Z. Y., Li, J. T., and Li, H. J. 2018. Pm61: A recessive gene for resistance to powdery mildew in wheat landrace Xuxusanyuehuang identified by comparative genomics analysis. Theor. Appl. Genet. 131:2085-2097.

Tan, C. C., Li, G. Q., Cowger, C., Carver, B. F., and Xu, X. Y. 2018. Characterization of $P m 59$, a novel powdery mildew resistance gene in Afghanistan wheat landrace PI 181356. Theor. Appl. Genet. 131:1145-1152.

The, T. T., McIntosh, R. A., and Bennett, F. G. A. 1979. Cytogenetical studies in wheat. IX. Monosomic analyses, telocentric mapping and linkage relationships of genes Sr21, Pm4, and Mle. Aust. J. Biol. Sci. 32:115-125.

Wang, Z. L., Li, L. H., He, Z. H., Duan, X. Y., Zhou, Y. L., Chen, X. M., Lillemo, M., Singh, R. P., Wang, H., and Xia, X. C. 2005. Seedling and adult plant resistance to powdery mildew in Chinese bread wheat cultivars and lines. Plant Dis. 89:457-463.

Wang, Z. Z., Li, H. W., Zhang, D. Y., Guo, L., Chen, J. J., Chen, Y. X., Wu, Q. H., Xie, J. Z., Zhang, Y., Sun, Q. X., Dvorak, J., Luo, M. C., and Liu, Z. Y. 2015. Genetic and physical mapping of powdery mildew resistance gene MlHLT in Chinese wheat landrace Hulutou. Theor. Appl. Genet. 128:365-373.

Werner, J. E., Endo, T. R., and Gill, B. S. 1992. Toward a cytogenetically based physical map of the wheat genome. Proc. Natl. Acad. Sci. 89:11307-11311.

Xiao, M. G., Song, F. J., Jiao, J. F., Wang, X. M., Xu, H. X., and Li, H. J. 2013. Identification of the gene Pm47 on chromosome 7BS conferring resistance to powdery mildew in the Chinese wheat landrace Hongyanglazi. Theor. Appl. Genet. 126:1397-1403.

Xie, J. Z., Wang, L. L., Wang, Y., Zhang, H. Z., Zhou, S. H., Wu, Q. H., Chen, Y. X., Wang, Z. Z., Wang, G. X., Zhang, D. Y., Zhang, Y., Hu, T. Z., and Liu, Z. Y. 2017. Fine mapping of powdery mildew resistance gene PmTm4 in wheat using comparative genomics. J. Integr. Agric. 16:540-550.

Xing, L. P., Hu, P., Liu, J. Q., Witek, K., Zhou, S., Xu, J. F., Zhou, W. H., Gao, L., Huang, Z. P., Zhang, R. Q., Wang, X., Chen, P. D., Wang, H. Y., Jones, J. D. G., Karafiatova, M., Vrana, J., Bartos, J., Dolezel, J., and Cao, A. Z. 2018. Pm21 from Haynaldia villosa encodes a CC-NBS-LRR that confers powdery mildew resistance in wheat. Mol. Plant 11:874-878.

Xu, H. X., Yi, Y. J., Ma, P. T., Qie, Y. M., Fu, X. Y., Xu, Y. F., Zhang, X. T., and An, D. G. 2015. Molecular tagging of a new broad-spectrum powdery mildew resistance allele $P m 2 c$ in Chinese wheat landrace Niaomai. Theor. Appl. Genet. 128:2077-2084

Xu, X. D., Li, Q., Ma, Z. H., Fan, J. R., and Zhou, Y. L. 2018. Molecular mapping of powdery mildew resistance gene $P m S G D$, in Chinese wheat landrace Shangeda using RNA-seq with bulk segregant analysis. Mol. Breed. 38:23.

Xue, F., Wang, C. Y., Li, C., Duan, X. Y., Zhou, Y. L., Zhao, N. J., Wang, Y. J., and Ji, W. Q. 2012. Molecular mapping of powdery mildew resistance gene in common wheat landrace Baihulu and its allelism with Pm24. Theor. Appl. Genet. 125:1425-1432.

Xue, F., Zhai, W. W., Duan, X. Y., Zhou, Y. L., and Ji, W. Q. 2009. Microsatellite mapping of powdery mildew resistance gene in wheat landrace Xiaobaidong. Acta Agron. Sin. 35:1806-1811.

Yahiaoui, N., Srichumpa, P., Dudler, R., and Keller, B. 2004. Genome analysis at different ploidy levels allows cloning of the powdery mildew resistance gene Pm3b from hexaploid wheat. Plant J. 37:528-538.

Yildirim, A., Sakin, M., Karadag, Y., Gokmen, S., Kandemir, N., Akkaya, M. S. and Yildirim, F. 2004. Genetic marker mediated transfer of an alien gene, Pm2 into wheat conferring resistance to powdery mildew. Biotechnol. Biotechnol. Equip. 18:15-19

Zeller, F. J., Lutz, J., and Stephan, U. 1993. Chromosome location of genes for resistance to powdery mildew in common wheat (Triticum aestivum L.).1 $M l k$ and other alleles at the Pm3 locus. Euphytica 68:223-229.

Zhang, Z. Y., Chen, X., Zhang, C., Xin, Z. Y., and Chen, X. M. 2002. Selecting the pyramids of powdery mildew resistance genes $P m 4 b, P m 13$, and $P m 21$ in wheat assisted by molecular marker. Sci. Agric. Sin. 35:789-793.

Zhao, X. H., Xu, H. X., Li, X. Q., and An, D. G. 2012. Genetic analysis of resistance to powdery mildew in three Chinese wheat landraces. Plant Prot. 38:51-54.

Zhao, Z. H., Huang, J., Lu, M., Wang, X. M., Wu, L. F., Wu, X. F., Zhao, X., and Li, H. J. 2013. Virulence and genetic diversity of Blumeria graminis f. sp. tritici in Shandong and Hebei provinces. Acta Agron. Sin. 39:1377-1385.

Zhou, R. H., Zhu, Z. D., Kong, X. Y., Huo, N. X., Tian, Q. Z., Li, P., Jin, C. Y., Dong, Y. C., and Jia, J. Z. 2005. Development of wheat near-isogenic lines for powdery mildew resistance. Theor. Appl. Genet. 110:640-648.

Zhuang, Q. S., and Li, Z. S. 1993. Present status of wheat breeding and related genetic study in China. Wheat Inf. Serv. 76:1-15.

Zou, S. H., Wang, H., Li, Y. W., Kong, Z. S., and Tang, D. Z. 2018. The NB-LRR gene Pm60 confers powdery mildew resistance in wheat. New Phytol. 218 298-309. 